\title{
Which public debt should be paid off?
}

\author{
Jonathan Pincus ${ }^{1}$
}

\section{Abstract}

This paper argues that the best reason for discouraging public debt is that such discouragement acts as a constraint on government spending.

Australian public debt has grown enormously since early 2020 and, unless fiscal settings change, the debt-to-GDP ratio is projected to remain around or above 40 per cent for decades. However, given risibly low interest rates, the burden of debt servicing has risen much more modestly. ${ }^{2}$ To what extent should the recent debt be paid off?

Although there are other considerations, what debt should be paid off should depend on the nature of the public spending that gave rise to it. It is useful to bear in mind two polar cases. First, when the debt has financed the creation of an asset capable of generating a string of current surpluses from which to service the debt fully then those surpluses should be used to pay off debt as the asset deteriorates. The second case is when the debt was incurred to finance spending that generated no such productive asset; here, the case for retiring the debt is harder to make and generally fails.

I suggest that the large part of the debt triggered by the Covid-19 pandemic is close to the second pole: having not created a remunerative asset. The issue here is not whether this debt-financed spending was justified in full or in part; the brute facts

\footnotetext{
$1 \quad$ University of Adelaide; jjpincus@gmail.com. The author thanks Henry Ergas for ideas and comments.

2 'But the future value of national income is now higher, because interest rates have fallen much more than future economic growth has fallen. So if we used the correct measure here- net debt to the current value of future national income- that too wouldn't have budged all that much' (Richardson, 2021).
} 
are that the debt has been incurred and it has not created an asset that could service the debt. The case for repaying it, therefore, is weak; we should regard the debt as though it were incurred in fighting a war; it should be rolled over at or before maturity, while allowing growth in real GDP and modest inflation to reduce it as a ratio to $\mathrm{GDP}{ }^{3}$

However, other non-remunerative public outlays should be funded out of taxation or other recurrent receipts, not debt, under the formerly fashionable rule of achieving recurrent balance over the economic cycle.

Much of the recent debt issue was quickly purchased by the Reserve Bank of Australia (RBA), monetising it. Some commentators have suggested the similar debt held by central banks be 'written off, which would severely damage the banks' balance sheets and, most likely, lead to an offsetting capital injection from governments, negating the 'write-off' except in an accounting sense. If, in contrast, the RBA retains these government securities or their rolled-over replacements, and thereby receives interest payments, it is likely that future governments will demand larger 'dividends' from the RBA into the Consolidated Revenue Fund and spend them.

In response to the pandemic, the federal and state governments made what can be properly regarded as massive social insurance payouts for events well beyond the remit of private insurance; ${ }^{4}$ they were emergency disaster payments, but ones outside the coverage of the preexisting Commonwealth-state agreements on disaster relief and other standing arrangements. The Commonwealth-state agreements cover idiosyncratic risks of disasters afflicting geographically limited regions or specific industries, including droughts, floods and cyclones, with the main purpose to relieve the affected state or territory governments of some of the costs of repairs to public infrastructure; but there are also emergency payments to individuals or businesses — some under preexisting arrangements (like the federal drought policy) or, quite commonly, ad hoc.

The novel characteristics of the Covid-19 payments are their scale and spread, reflecting a reasonable judgement that, without them, the damage to economic and social life would have been huge and hugely disruptive, and longer lasting. They were social insurance payments for the consequences of a largely uninsurable,

3 In 1946, Australia had a ratio of debt to GDP of 125 per cent, which by 1952 had fallen to 22 per cent. However, with no additions or redemptions of the 1946 debt, inflation alone would have caused a halving of the ratio and the rise in real GDP itself would have reduced it by more than one-quarter. Author's calculations using Vamplew (1987, ANA 129, GF 14, PC 20). For the international post-World War I experience, see Dabla-Norris (2019).

4 However, in recent years, catastrophe bonds (or 'cat bonds') have been issued by private-sector entities (such as insurance companies), governments (such as Mexico's) and international organisations (such as the International Monetary Fund and the World Health Organization) against localised catastrophes like earthquakes or hurricanes, and financed by investors seeking assets with returns uncorrelated with fixed interest bonds and equities (see en.wikipedia. org/wiki/Catastrophe_bond). The only issuer of pandemic bonds has been the International Bank for Reconstruction and Development in relation to Ebola (Fernyhough, 2020). 
systemic, society-wide event. What are governments for, if they do not fulfil such implicit social insurance contracts, especially in Australia's fiscal circumstances of initially low public debt and very low interest rates?

This is not to imply that the spending was fully and perfectly justified in every aspect, but to assert its general characteristics. ${ }^{5}$ What, then, to do about the debt? What should be the fiscal rules from now on?

In a blog entry, extracting from his forthcoming book entitled Economic Consequences of the Pandemic, the socialist and democrat John Quiggin wrote:

The bigger question is: in the absence of any apparent constraint on our ability to finance current spending with long-term debt, what policy approach should replace the now-discredited goals of balanced budgets and zero debt. The answer is to consider fiscal policy in terms of the need to match aggregate demand (public and private) with the productive capacity of the economy, taking account of the appropriate balance between consumption and investment.

This way of thinking about things comes naturally to old-school Keynesians.

This suggests a policy of matching the maturity of financing public spending with the effective duration of that spending. Current expenditure, such as transfer payments, should, under normal conditions, be financed by taxation. Long-term investments in physical, human or social capital should be financed by bonds with a maturity similar to that of the investment's lifetime. This approach is broadly consistent with the accrual accounting framework introduced in the 1990s, but left to languish as governments returned to a focus on misleading, but seemingly more comprehensible cash-based measures.

If this approach is adopted consistently, the long-term equilibrium will be one in which the ratio of public debt to GDP will be determined by the stock of public investments in physical and human capital. (Quiggin, 2020)

How would Quiggin's 'Keynesian maturity matching' have guided the government during 2020 and 2021? The massive spending was mostly not a Keynesian demand stimulus; the main economic impacts of the virus itself and of government regulatory responses and spontaneous private reactions were on the supply side, via huge cuts in 'non-essential' supply and prohibitions on catering to demand in accustomed face-to-face ways. Much of the governmental pandemic outlay was on support of the unemployed and underemployed workers and some owners of private enterprise. These were, as argued earlier, largely emergency welfare payments sparked by a systemic disaster, although some were 'investment' in reducing the

5 To a large extent, the spending was triggered by the public health policies of the states but would not have occurred without the pandemic. 
hysteresis effect of periods of unemployment and in the longer-term viability of some private enterprises. ${ }^{6}$ (The payments to the retired could be thought of as an attempt at demand stimulus, however, they seem to have been saved, at least temporarily.)

The emergency payments are also an investment in maintaining the trust of Australians in our democratic political system.

Therefore, Quiggin's rule for 'normal circumstances' would seem to require an instant and massive rise in tax receipts, which would be inconsistent with the teaching of 'old-school Keynesianism'.

Thus, it seems that Quiggin's rule applies to the budget minus the carryover of Covid-induced debt. The increase in debt did not finance an equivalent quantum of investment, as has just been argued. How to service it and how or whether to pay it off? Quiggin made no suggestion, but there is a hint in his mention of the achievement of 'a long-term equilibrium' where the quantum of debt is no more than the value of remunerative assets, which implies that the Covid debt will somehow disappear.

As for 'external' debt, there may be two precautionary arguments for paying some off, due first to a concern that the market rate of interest will rise, especially if inflation is sparked by the pervasive loose monetary policy; and, second, to provide a reservoir of overseas borrowing capacity for times when Australia's interests would be best served by a temporary deterioration in the balance of international trade. For the 'domestic' debt, account should also be taken of the extent to which it displaces private debt in private portfolios and, therefore, lessens the Australian supply of funds for real investment. For both kinds of debt, however, there is a public choice-like claim that paying it off sends a signal of disapproval of debt that is not matched by remunerative investment. None of these considerations offers a strong case for substantial or complete repayment.

I turn now to other-than-Covid debt. In suggesting restricting bond financing to 'long-term investments', to not push up the ratio of public debt to GDP, Quiggin presumably had in mind the first polar case outlined earlier —of investments that boost the fiscal capacity sufficiently to service their associated debt, rather than merely being spending that generates some benefits or revenues into the future. ${ }^{7}$

When interviewed for the Legislative Council's oral history project, Michael Egan volunteered that, during his decade as NSW Treasurer (April 1995 to January 2005):

\footnotetext{
6 However, the payments to firms reduced the extent of 'normal' bankruptcies of so-called zombie firms.

7 Arithmetic says the ratio of debt to GDP does not rise if the growth rate of debt is no more than the growth rate of GDP. Even then, however, as Quiggin is clearly aware, the burden on GDP would rise if the relevant interest rates rose.
} 
[The] most significant achievement was fiscal consolidation. We paid off the general government net debt, which I think left us in very good stead in the last decade ... One of the things we agreed to immediately on coming to government and then implemented was all the national competition reforms ... We corporatised all of our government businesses and we entered the national energy market. (Legislative Council, 2016)

Egan's aim-largely met - was to borrow only for 'remunerative' investments and otherwise balance the budget 'over the cycle'. I think, by remunerative, Egan meant investments that, without rises in tax rates or charges, generated a flow of additional public revenue sufficient to service the debt.

This constraint — restricting the issuance of new debt to 'remunerative' investmentsEgan partly justified on the grounds that it accorded with the principle of competitive neutrality within the National Competition Policy, which required corporatised government businesses to generate operational profits sufficient to provide a 'competitive' return to equity, after servicing their debt (principal as well as interest $)^{8}$ and paying the equivalent of company and other taxes. With these conditions met, the operations placed no net fiscal burden on the public sector and caused no increase in uncovered debt; and the ordinary commercial accounts of the businesses provided the Treasurer with most of the necessary information. ${ }^{9}$ All other spending was to be financed from general revenue-mostly state taxes and charges and federal grants.

Egan's fiscal framework differed interestingly from that proposed in 1924 by the NSW Valuer-General in justifying railway deficits at a time when railway finances dominated the state's public accounts:

The Income Tax Commissioner, the Land Tax Collector, the Excise Officer, each has his receipts swelled through railway facilities ... No department is entitled to look only at its parochial aspects — sprats must be cast to catch mackerel ... In the long run it is perfectly immaterial whether the Lands Department made a profit, or the Valuer General's Department made a profit, so long as the State as a whole is able to balance its accounts ... I have always thought the State ought to view their various operations as one big company rather than a segregation of companies. (Cited in Butlin et al., 1982, p. 264)

Note first that the valuer-general's budget test was to be applied at an aggregate level, whereas Egan's concerned the disaggregated or 'segregated' level. However, once we consider how to employ the valuer-general's 'whole-of-government' framework as a prospective guide to public spending, it would seem to require projections at the 'segregated' level. Say the draft budget showed an overall deficit: where should

8 Debt could be rolled over at maturity only if the 'asset' or activity continued to generate the required cash surpluses. Otherwise, a sinking fund would be required. This, presumably, is what Quiggin had in mind in his discussion of matching the maturity of the debt with that of the asset.

9 The operation of the system of horizontal fiscal equalisation was a complication. 
spending be cut? It would increase the deficit were spending to be reduced in areas that 'made a profit'. That is, for its implementation, the valuer-general's test required an accurate allocation of credit for revenues to the various components of public spending — or, more strictly, their separate net fiscal effects (as does Egan's). ${ }^{10}$

The second and real difference was that the valuer-general was cognisant of the possibility of positive fiscal spillovers, not only from state-owned enterprises, but also from the activities of general government.

So, to expand on the second difference between Egan's conservative fiscal framework and the valuer-general's more liberal one: if we classify as 'investment' any spending that generates benefits beyond the budget year, there are many groups, including public employees of the relevant department or section, who are keen to argue that all manner of public spending has at least an element of investment. However, this is not a sufficient condition for an improvement in economic efficiency or welfare. Rather, what is needed is evidence that an additional specific expenditure would generate net benefits when account is taken of spillovers as well as direct costs and benefits.

When fiscal spillovers are grafted on to Egan's 'segregation of companies', the budget criterion would be something like the following: items of debt-financed spending were justified if they boosted the state's revenue capacity sufficiently to allow the government to continue to service the higher debt without requiring an increase in tax rates or a broadening of the base of existing taxes and charges or creation of new ones. If this criterion were applied at the disaggregated level, the valuer-general's test would be satisfied at the aggregate, whole-of-government level.

But government is not a company, so there is an argument that it should not be bound by the rules of fiscal sustainability at unchanged rates of taxes and charges; when implemented in its usual forms, a criterion that focuses solely on the fiscal outcome does not provide a direct test of the effects of a public policy on economic efficiency or community welfare. ${ }^{11}$ Therefore, the usual cost-benefit analyses of public spending do not impose the constraint, advocated by Quiggin, that there be no induced rise in the ratio of public debt to GDP.

(As an indicator of economic efficiency, the earliest best-practice cost-benefit analyses used GDP supplemented by imputed values for non-marketed goods and services, positive or negative. Interestingly, when computable general equilibrium

\footnotetext{
10 Before the advent of sophisticated quantitative models, the fiscal test was applied to items of spending, if at all, mostly using rules of thumb. For an extension or upgrade of transport infrastructure, for example, a crude version was applied of what later became known in the economics literature as the 'Henry George theorem': the projected additional traffic was used as a proxy for the endogenous increase in local land values, which was taken as an indicator of the boost to public revenue from public land sales or leases (see Ergas \& Pincus, 2015, p. 233).

11 There are, however, circumstances in which, given no change in the tax system, a rise in tax revenue is a measure of the rise in economic output (see Kaplow, 2008, Part I).
} 
models are employed to generate estimates of net benefits, they commonly assume that any incipient endogenous public deficit is offset by the imposition of a 'lumpsum' tax, which has no detrimental effects on economic activity. Given the high estimated marginal excess burdens of most taxes, this leads to an overestimate of the net benefit.)

This raises a question: to the extent that education or other spending creates or preserves human capital, why does it matter whether it is financed by public debt or by private debt of the student (here, regarding HECS-HELP liabilities as private debt)? Clearly, distributional consequences can flow from this choice, but what other first-order effects are in play?

Rent-seekers who push for more spending of specific kinds tend to present their favoured spending as 'investment', and can find economic consultants, or even the Productivity Commission, to back them up-see the report into the proposed National Disability Insurance Scheme (NDIS) (Productivity Commission, 2011). In this report, the proposed spending was mostly justified on a utilitarian basisspecifically, redistribution from the abled to the (generally lower-income) disabled, generating 'efficiency' gains. As this would have been far from 'remunerative' in Egan's sense, the commission sought to find labour market responses that produced the fiscal effect of the NDIS 'paying for itself'. But, in a benevolent dictatorship world, there is no justification for requiring Egan's test to be met; utilitarianism does not require it.

My own view is that the best reason for discouraging public debt is that it acts as a constraint on public spending, which is why James Buchanan advocated for a constitutional balanced-budget amendment:

The most elementary prediction from public choice theory is that in the absence of moral or constitutional constraints democracies will finance some share of current public consumption from debt issue rather than from taxation and that, in consequence, spending rates will be higher than would accrue under budget balance.

(Buchanan, quoted in Tempelman, 2007, p. 435)

A fuller normative case against public debt turns on the incentive effects of debt financing, and on the incidence of the burden of debt, which in turn depends on the strength of the Ricardo-Barro effect whereby prospective taxpayers suffer a subjective diminution of wealth due to their capitalising future tax obligations arising from debt servicing (Tempelman, 2007). Resources used up today are lost to tomorrow, unless they have generated productive assets, so it seems strange and unfair to burden tomorrow's taxpayers not only with covering the interest payments (rather than issuing new debt for that purpose), but also with the burden of retiring the Covid-19 debt. 


\section{References}

Butlin, N.G., Barnard, A. \& Pincus, J.J. (1982). Government and capitalism: Public and private choice in twentieth century Australia. Allen \& Unwin.

Dabla-Norris, E. (ed.). (2019). Debt and entanglements between the wars. International Monetary Fund.

Ergas, H. \& Pincus, J.J. (2015). Infrastructure and colonial socialism. In S. Ville \& G. Withers (eds), The Cambridge economic history of Australia. Cambridge University Press. doi.org/ 10.1017/CHO9781107445222.015.

Fernyhough, J. (2020). Coronavirus to trigger pandemic catastrophe bonds. Australian Financial Review, 9 March. Available from: www.afr.com/companies/financial-services/ coronavirus-to-trigger-pandemic-catastrophe-bonds-20200309-p5483y.

Kaplow, L. (2008). The theory of taxation and public economics. Princeton University Press. doi.org/10.2139/ssrn.1155194.

Legislative Council. (2016). Oral history project. [Transcript], Sydney, 9 February. Available from: www.parliament.nsw.gov.au/lc/roleandhistory/Documents/Egan $\% 20$ $-\% 20$ transcript.pdf.

Productivity Commission. (2011). Disability care and support: Inquiry report. Australian Government. Available from: www.pc.gov.au/inquiries/completed/disability-support/ report. doi.org/10.2139/ssrn.2006098.

Quiggin, J. (2020). Public debt after the pandemic. [Blog], 30 December. Available from: johnquiggin.com/2020/12/30/public-debt-after-the-pandemic/.

Richardson, C. (2021). Why Australia's national debt is not as bad as it looks. Australian Financial Review, 11 January, 56. Available from: www.afr.com/policy/economy/whyaustralia-s-national-debt-is-not-as-bad-as-it-looks-20210110-p56t15.

Tempelman, J.H. (2007). James M. Buchanan on public-debt finance. The Independent Review, XI(3), 435-49. Available from: www.independent.org/pdf/tir/tir_11_03_06_ templeman.pdf.

Vamplew, W. (1987). Australian historical statistics. Fairfax, Syme \& Weldon Associates. 
This text is taken from Agenda, Volume 28 - Number 1, 2021 edited by William Coleman, published 2021 by ANU Press, The Australian National University, Canberra, Australia.

doi.org/10.22459/AG.28.01.2021.07 